\title{
Türk ve Filtre Kahve Örneklerindeki Toplam Antioksidan Kapasitelerin Elektrokimyasal Yöntemlerle Belirlenmesi
}

\author{
Sevinç Yıldırım ${ }^{1}$, Ersin Demir ${ }^{2 *}$, İlkay Gök ${ }^{3}$ \\ Geliş / Received: 13/05/2020 \\ Revize / Revised: 02/06/2020 \\ Kabul / Accepted: 03/06/2020
}

\section{$\overline{\mathbf{O Z Z}}$}

Bu çalışmada, az, orta ve koyu gibi değişik derecelerde farklı kavrulmuş kahve çekirdekleriyle demlenen Türk ve Filtre kahvelerindeki toplam antioksidan kapasitesinin (TAC) belirlenmesi için dönüşümlü (CV), kare dalga siyırma (SWSV) ve diferansiyel puls siyırma (DPSV) voltametrik yöntemlerle kullanıldı. Voltametrik parametreleri, karbon pasta elektrotu (CPE) kullanılarak pH 4.0 Britton-Robinson tampon çözeltisinde optimize edildi. Standart antioksidan maddeleri olarak gallik asit ve kuersetin'in elektrokimyasal davranışı CPE üzerinde optimum koşullar altında CV, SWSV ve DPSV teknikleri ile incelendi. Her üç elektrokimyasal tekniklerle (CV, SWSV, DPSV) gallik asit için yaklaşık $350 \mathrm{mV}$ ve $700 \mathrm{mV}$ 'ta olmak üzere iki oksidasyon piki görülürken, kuersetin için ise $340 \mathrm{mV}, 725 \mathrm{mV}$ ve $1015 \mathrm{mV}$ 'larda anodik pikleri elde edildi. Bununla birlikte, kahve örneklerindeki toplam antioksidan kapasitelerini eşdeğer gallik asit ve kuersetin cinsinden belirlemek için CPE kullanılarak pH 4.0'da her iki maddeye ait yaklaşık 350 mV'de anodik pik akımları tercih edildi. Az kavrulmuş kahve çekirdekleriyle hazırlanan kahve örneklerinde maksimum antioksidan kapasite (TAC) gösterdiği bulundu. Az kavrulmuş kahve çekirdekleri ile hazırlanan Türk kahvesi için TAC değeri, CV yöntemi kullanılarak 17.868 $\pm 0.281 \mathrm{~g} / \mathrm{L}$ ve $65.165 \pm 1.024 \mathrm{~g} / \mathrm{L}$ eşdeğer gallik asit ve kersetin olarak hesapland. Ayrıca, Filtre kahvesi için, TAC değerleri sırasıyla $32.290 \pm 0.839 \mathrm{~g} / \mathrm{L}$ ve $118.471 \pm 3.529 \mathrm{~g} / \mathrm{L}$ olarak bulundu. Dahasi, tüm kahve örneklerindeki TAC değerleri CV'nin yanı sıra DPSV ve SWSV ile analiz edildi. Sonuç olarak, elektrokimyasal yöntemlerle, hızlı, ucuz ve ön işlemlere tabi tutulmadan doğrudan gıda örneklerinde TAC analizi edilmektedir.

\footnotetext{
1İletişim: sevinc.yildirim@okan.edu.tr (https://orcid.org/0000-0001-57933-2333)

Uygulamalı Bilimler Fakültesi, Gastronomi Bölümü, İstanbul Okan Üniversitesi, İstanbul Türkiye

2*Sorumlu yazar iletişim: dr.ersindemir@yahoo.com (https://orcid.org/0000-0001-9180-0609)

Eczacılık Fakültesi, Analitik Kimya Ana Bilim Dalı, Afyonkarahisar Sağlık Bilimleri Üniversitesi, Afyonkarahisar, Türkiye

3̇letişim:ilkay.gok@okan.edu.tr (https://orcid.org/0000-0002-4871-8981)

Uygulamalı Bilimler Fakültesi, Gastronomi Bölümü, İstanbul Okan Üniversitesi, İstanbul Türkiye
} 


\title{
Determination of Total Antioxidant Capacities in Turkish and Filter Coffee Samples by Electrochemical Methods
}

\begin{abstract}
In this study, cyclic (CV), square wave stripping (SWSV) and differential pulse stripping voltammetric (DPSV) methods were used to determine total antioxidant capacity (TAC) in Turkish and Filter coffees brewed with differently roasted coffee beans such as light, medium and dark. Voltammetric parameters were optimized in $\mathrm{pH}$ 4.0 Britton-Robinson buffer solution using carbon paste electrode (CPE). Electrochemical behavior of gallic acid and quercetin as standard antioxidant substances were investigated on CPE under optimum conditions by $\mathrm{CV}$, SWSV and DPSV. With all three electrochemical techniques (CV, SWSV, DPSV), two oxidation peaks were observed for gallic acid approximately at $350 \mathrm{mV}$ and $700 \mathrm{mV}$, while anodic peaks were obtained for quercetin at $340 \mathrm{mV}, 725 \mathrm{mV}$ and $1015 \mathrm{mV}$. However, anodic peak currents at $350 \mathrm{mV}$ for both substances were preferred using CPE to determine total antioxidant capacities in coffee samples in terms of equivalent gallic acid and quercetin. It was found that coffee samples prepared by light roasted coffee beans showed maximum antioxidant capacity (TAC). TAC values for Turkish coffee prepared with less roasted coffee beans were calculated as $17.868 \pm 0.281 \mathrm{~g} / \mathrm{L}$ and $65.165 \pm 1.024 \mathrm{~g} / \mathrm{L}$ equivalent gallic acid and quercetin using $\mathrm{CV}$ method. Also, TAC values for filter coffee were $32.290 \pm 0.839 \mathrm{~g} / \mathrm{L}$ and $118.471 \pm 3.529 \mathrm{~g} / \mathrm{L}$, respectively. Moreover, TAC values in all coffee samples were also analyzed with DPSV and SWSV as well as CV. As a result, TAC analysis is carried out directly on food samples with electrochemical methods, fast, cheap and without pre-treatment.
\end{abstract}

Keywords- Coffee, Antioxidant, Electrochemistry, Voltammetry 


\section{INTRODUCTION}

Antioxidants can be described briefly as substances that stop or negate the adverse effects and formation of free radicals in the human body and foods [1-2]. Oxidative stress caused by free radicals adversely affects human health [3]. The oxidative stress can seriously damage lipids, proteins, enzymes, carbohydrates and DNA. Furthermore, they cause random breaks in DNA chains, damage to enzymes and structural proteins, cancer, neurodegenerative and cardiovascular diseases [3-5]. Therefore, antioxidants are one of the most important food sources for healthcare individuals [6-7]. Both endogenous (natural) and exogenous (artificial) origin antioxidants intake is of great importance for human health [8]. The endogen (natural) antioxidants are produced by the organism, while exogenous antioxidants are herbal sources [9-10]. Antioxidant substances that only organisms can produce are not enough for human health. In addition, the human body needs plant-based antioxidants [11]. For these reasons, antioxidant-rich food materials and their consumption has become the basic need for healthy individuals. Many natural beverages, especially fruits and vegetables, are known to contain antioxidant substances [12]. Coffee, a soft drink, comes at the beginning of these beverages which are contains a large amount antioxidant according due to their rich components [13-15].

Coffee, belonging to the Rubiaceae family and of the genus Coffea, was named after Kaffa, a city in Ethiopia [16]. It is one of the oldest soft drinks globally. A near history of 1000 years, coffee is one of the most consumed beverages in the world [17]. The most efficient coffee growing places are tropical regions and maximum coffee bean harvest is obtained in moist and cool regions. Coffee, which is a very delicate and fragile plant species, has now been identified as nearly 100 plant types in the main floor [17]. Coffee contains more than 1000 nutrients and flavors, mainly caffeine, carbohydrates, lipids, vitamins, nitrogenous compounds and micronutrients [18-19]. Many studies are carried out by scientists in coffees, which are quite remarkable in terms of antioxidants [20-22]. Most of these studies are spectrophotometric and chromatographic methods. The antioxidants determinations in coffee samples have been carried out by oxygen radical absorbance capacity (ORAC)[23], total radical-trapping antioxidant parameter (TRAP) [14], trolox equivalent antioxidant capacity method (TEAC) [24], 2,2-diphenyl-1-picrilhydrazyl (DPPH) radical scavenging capacity method [25], copper (II) ion reduction based antioxidant capacity method (CUPRAC) [26], iron (ii) ion reducing antioxidant power method (FRAP) [27] and Folin-Ciocalteu reactive (FCR) method [28]. However, cheaper, faster, more precise and reliable new methods are required for antioxidant determinations due to the use of many non-environmentally friendly solvents, long pretreatment and expensive equipment are required from these classical methods. While this is the case, electrochemical methods are successfully used in the determination of numerous drugs, pesticides, amino acids and antioxidant substances [29-31]. Moreover, considering important validation parameters such as time, cost, precision and portable, electrochemical methods show great superiority. In addition, countless new sensors have been constructed nowadays for many trace levels of antioxidant determinations in food samples [32-36].

The antioxidant determinations in differently roasted coffee varieties with the electrochemical methods rarely used in antioxidant determinations were performed for the first time with this study. In this work, the total antioxidant capacities (TAC) of Turkish and Filter coffee samples brewed using roasted coffee beans such as light, medium and dark were investigated voltammetric methods on a carbon paste electrode (CPE). Electrochemical behaviors of gallic acid and quercetin as references antioxidant agents were explored in detail cyclic (CV), square wave stripping (SWSV) and differential pulse stripping (DPSV) voltammetric methods in pH 4.0 Britton-Robinson buffer solutions. TAC values in two coffee samples by prepared with three different beans were calculated in terms of equivalent to gallic acid and quercetin by using CV, SWSV and DPSV methods on CPE. Consequently, TAC values in coffee samples were successfully analyzed using fast, economical and environmentally friendly voltammetric methods. Therefore, novel analytical methods have been developed for antioxidant determinations in coffee samples and contribution of this manuscript will be made to the literature in terms of determination TAC in coffee sample. 


\section{EXPERIMENT}

\section{A. Apparatus}

All data were collected by using Vertex ${ }^{\circledR}$ One (Ivium) electrochemical analyzer combined with a solid electrode cell stand. This system consists of three electrodes such as reference (Ag/AgCl; BASi, MF-2052), counter (platinum wire; BASi, MW-1032). and working electrodes (Carbon paste electrode (CPE); BASi MF2010). For the determination of antioxidant in coffee, cyclic voltammetry (CV), differential pulse stripping voltammetry (DPSV) and square wave stripping voltammetry (SWSV) methods were applied on CPE in pH 4.0 Brittion-Robinson (B-R) buffer solutions. Mettler Toledo brand $\mathrm{pH}$ meter with an accuracy of \pm 0.05 .

\section{B. Reagents}

Gallic acid and quercetin were obtained from Aldrich-Sigma at as analytical standard. The stock solutions of gallic acid and quercetin were prepared as a concentration of $500 \mathrm{mg} / \mathrm{L}$ by water and ethanol, respectively. Britton Robinson buffer solution used for support electrolyte was prepared with acetic acid, orthophosphoric and boric acid to be $0.04 \mathrm{M}$. To adjust the buffer to $\mathrm{pH} 4.0,2.0 \mathrm{M} \mathrm{NaOH}$ or $2.0 \mathrm{M} \mathrm{HCl}$ solutions were preferred. Distilled water was used in all processes such as solution preparation and washing.

\section{Preparation of working electrode}

In the construction of carbon paste electrode $(\mathrm{CPE})$ as an indicator electrode, $70 \%$ graphite powder $(<150 \mu \mathrm{m})$ by mass was treated with $30 \%$ mineral oil. These two mixtures were mixed until homogeneous. The formed homogeneous carbon paste was placed in the $3 \mathrm{~mm}$ diameter area at BASi-MF 2010 electrode with a syringe. Before using CPE, polishing was applied to the electrode surface with soft sandpaper. Finally, after polishing, the electrode was washed with distilled water and dried at room temperature.

\section{Process preparation of coffee samples}

All coffee beans were obtained from the commercial coffee producer company. Coffee beans were roasted light, medium and dark at three different temperatures. Filter and Turkish coffees are ground according to the brewing type. For Turkish coffee samples, 7.0 grams of finely weighed coffee beans ground into fine powder were obtained by using the Arzum Okka machine. Brewed Turkish coffees were cooled at room temperature and centrifuged for 5 minutes. The coffee beans used in making filter coffee were weighed precisely as 7.0 grams as in Turkish coffee. Three types of filter coffee samples were obtained using SINBO SCM 2938 machine. The coffee samples were then cooled to room temperature and centrifuged at $3000 \mathrm{rpm}$ for 5 minutes. All coffee samples were stored at $-20^{\circ} \mathrm{C}$ in the freezer when not in use.

\section{RESULTS AND DISCUSSION}

\section{A. Cyclic Voltammetry}

Firstly, the electrochemical behavior of gallic acid and quercetin at $2 \mathrm{mg} / \mathrm{L}$ was examined with a carbon paste electrode (CPE) in a pH 4.0 Britton-Robinson buffer solution. Cyclic voltammograms were obtained for these standard antioxidant compounds between -200 and $+1400 \mathrm{mV}$ at a scanning rate of $100 \mathrm{mV} / \mathrm{s}$ (Figure 1). Gallic acid exhibited two anodic peaks at $360 \mathrm{mV}$ and $727 \mathrm{mV}$ by CV. For the quercetin, three oxidation peaks were observed, $350 \mathrm{mV}, 735 \mathrm{mV}$ and $1025 \mathrm{mV}$ on CPE in $\mathrm{pH}$ 4.0. In the cathodic scanning, no reduction peak was obtained for both items. Therefore, it can be said that it has an irreversible electrode reaction for both substances. In addition, predominant anodic peak currents of approximately $350 \mathrm{mV}$ for both substances were taken as reference for the antioxidant determinations in coffee samples ( $\mathrm{pH}$ 4.0 BR buffer solution, scan rate $=$ $100 \mathrm{mV} / \mathrm{s}, \mathrm{CPE})$. 


\begin{tabular}{|c|c|c|}
\hline & $\begin{array}{l}\text { BŞEÜ Fen Bilimleri Dergisi } \\
7(1), 382-393,2020\end{array}$ & $\begin{array}{r}\text { BSEU Journal of Science } \\
\text { DOI: } 10.35193 / \text { bseufbd.736123 }\end{array}$ \\
\hline U & & $8-7575$ (http://dergipark.gov.tr/bseufbd) \\
\hline
\end{tabular}

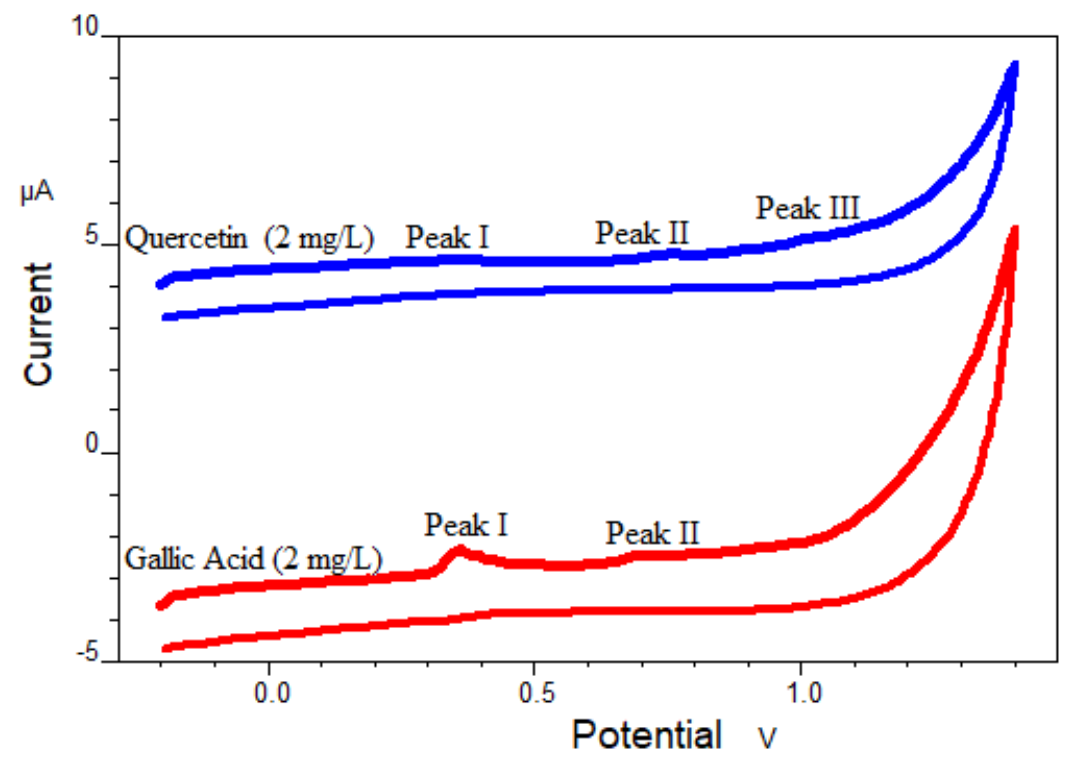

Figure 1. Cyclic voltammograms for the gallic acid and quercetin $(\mathrm{pH} 4.0 \mathrm{BR}$ buffer solution, scan rate $=100 \mathrm{mV} / \mathrm{s}$ )

$\mathrm{CV}$ measurements for the Turkish and Filter coffee samples brewed with different roasted beans were taken under optimum conditions determined for reference antioxidant substances on CPE in pH 4.0 BR buffer solution (Figure 2).
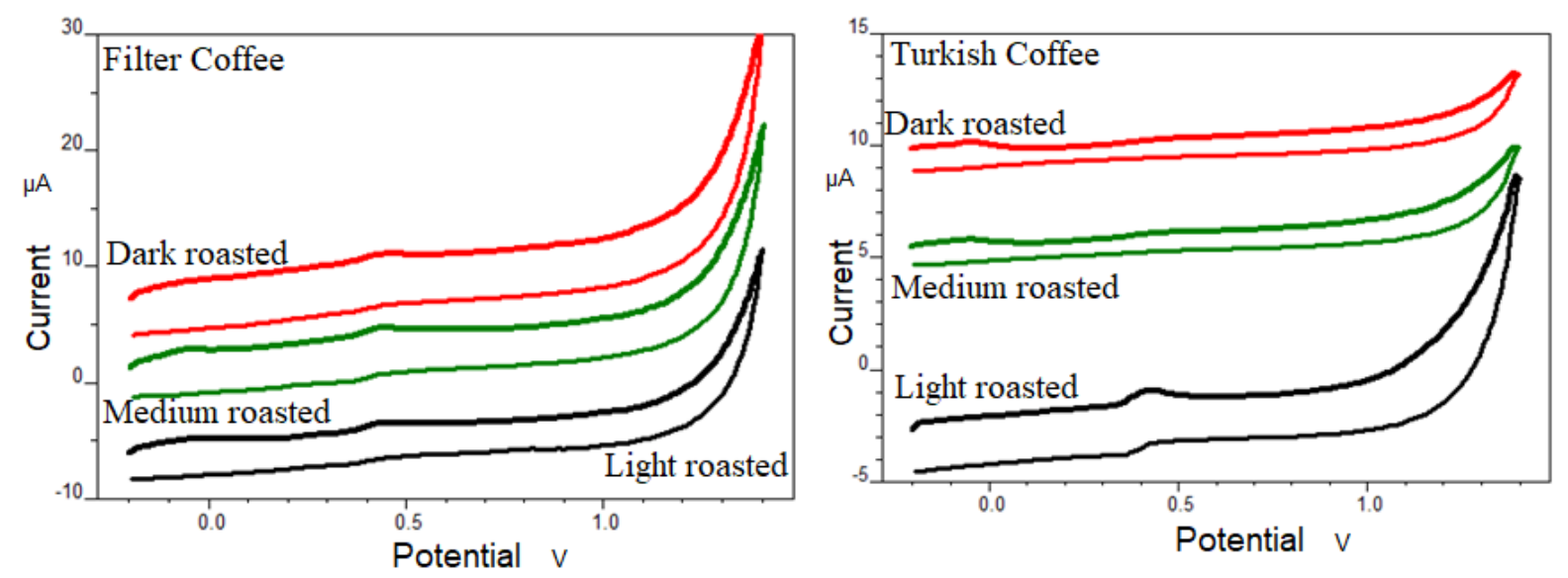

Figure 2. Cyclic voltammograms of Turkish and Filter Coffee samples prepared with different coffee beans ( $\mathrm{pH} 4.0 \mathrm{BR}$ buffer solution, scan rate $=100 \mathrm{mV} / \mathrm{s}, \mathrm{CPE})$

According to the results of the $\mathrm{CV}$, it has been found that it contains the most antioxidant capacity (TAC) in Turkish and Filter coffees prepared with low roasted coffee beans (Table 1). For Turkish coffee, the TAC in terms equivalent of gallic acid and quercetin was as $17.868 \pm 0.281$ and $65.165 \pm 1.024$, respectively. These values for filter coffee were found as $13.290 \pm 0.419$ and $48.471 \pm 1.529$. According to the method of roasting, there was a significant decrease in the amount of antioxidants in both coffees prepared with medium and dark coffee beans. 
Table 1. Total TAC values as equivalent gallic acid and quercetin by CV for Turkish and Filter coffee samples, $n=3$.

\begin{tabular}{|c|c|c|c|c|}
\hline \multirow{3}{*}{ Coffee Bean } & \multicolumn{2}{|c|}{$\begin{array}{c}\text { Equivalent } \\
\text { Gallic Acid }(\mathrm{g} / \mathrm{L})\end{array}$} & \multicolumn{2}{|c|}{$\begin{array}{c}\text { Equivalent } \\
\text { Quercetin (g/L) }\end{array}$} \\
\hline & \multicolumn{2}{|c|}{ Brewing technique } & \multicolumn{2}{|c|}{ Brewing technique } \\
\hline & Turkish coffee & Filter coffee & Turkish coffee & Filter coffee \\
\hline Light roasted & $17.868 \pm 0.281$ & $32.290 \pm 0.839$ & $65.165 \pm 1.024$ & $118.471 \pm 3.529$ \\
\hline Medium roasted & $0.997 \pm 0.019$ & $8.880 \pm 0.226$ & $3.635 \pm 0.071$ & $32.389 \pm 0.824$ \\
\hline Dark roasted & --- & $0.580 \pm 0.012$ & --- & $2.106 \pm 0.048$ \\
\hline
\end{tabular}

\section{B. Square Wave Stripping Voltammetry}

Square wave stripping voltammetry (SWSV) is the most frequently used and highly sensitive, selective and fast method among electrochemical methods has been used in qualitative and quantitative analysis of many electro-active analytes. Optimal experimental conditions of SWSV, another analytical chemistry method which is more sensitive, selective and precision were determined for the determination of gallic acid and quercetin (Table 2).

Table 2. Optimum module parameters of SWSV technique on carbon paste electrode (CPE)

\begin{tabular}{lc}
\hline Parameters & Optimum Values \\
\hline Pulse Amplitude $(\Delta \mathrm{E})$ & $50 \mathrm{mV}$ \\
Frequency $(f)$ & $100 \mathrm{~Hz}$ \\
Step Potential $\left(\Delta \mathrm{E}_{\mathrm{b}}\right)$ & $5 \mathrm{mV}$ \\
Accumulation Potantial $\left(\mathrm{E}_{\mathrm{b}}\right)$ & $0 \mathrm{mV}$ \\
Accumulation Time $\left(\mathrm{t}_{\mathrm{b}}\right)$ & $30 \mathrm{~s}$ \\
Support Electrolyte & $\mathrm{pH} 4.0$ Britton-Robinson buffer \\
\hline
\end{tabular}

Two oxidation peaks at $350 \mathrm{mV}$ and $675 \mathrm{mV}$ were observed for $0.5 \mathrm{mg} / \mathrm{L}$ gallic acid on carbon paste electrode (CPE) under experimental conditions of SWSV (Figure 3). For the quercetin, three anodic peaks were obtained at $350 \mathrm{mV}, 735 \mathrm{mV}$ and $1020 \mathrm{mV}$ in pH pH 4.0 Britton-Robinson buffer solutions on CPE. However, since the density of anodic peaks at $675 \mathrm{mV}$ for gallic acid and $735 \mathrm{mV}$ and $1025 \mathrm{mV}$ for quercetin is very low, the peak currents at $350 \mathrm{mV}$ were used when calculating the total antioxidant capacity (TAC) as equivalent gallic acid and quercetin in coffee samples.

Table 3. Total TAC values as equivalent gallic acid and quercetin by SWSV for Turkish and Filter coffee samples, $\mathrm{n}=3$.

\begin{tabular}{|c|c|c|c|c|}
\hline \multirow{3}{*}{ Coffee Bean } & \multicolumn{2}{|c|}{$\begin{array}{c}\text { Equivalent } \\
\text { Gallic Acid }(\mathrm{g} / \mathrm{L}) \\
\end{array}$} & \multicolumn{2}{|c|}{$\begin{array}{c}\text { Equivalent } \\
\text { Quercetin }(\mathrm{g} / \mathrm{L})\end{array}$} \\
\hline & \multicolumn{2}{|c|}{ Brewing technique } & \multicolumn{2}{|c|}{ Brewing technique } \\
\hline & Turkish coffee & Filter coffee & Turkish coffee & Filter coffee \\
\hline Light roasted & $40.143 \pm 1.143$ & $92.869 \pm 2.613$ & $19.580 \pm 0.558$ & $45.298 \pm 1.274$ \\
\hline Medium roasted & $7.254 \pm 0.285$ & $42.006 \pm 1.757$ & $3.538 \pm 0.139$ & $20.489 \pm 0.857$ \\
\hline Dark roasted & $1.519 \pm 0.019$ & $14.072 \pm 0.446$ & $0.741 \pm 0.009$ & $6.864 \pm 0.218$ \\
\hline
\end{tabular}




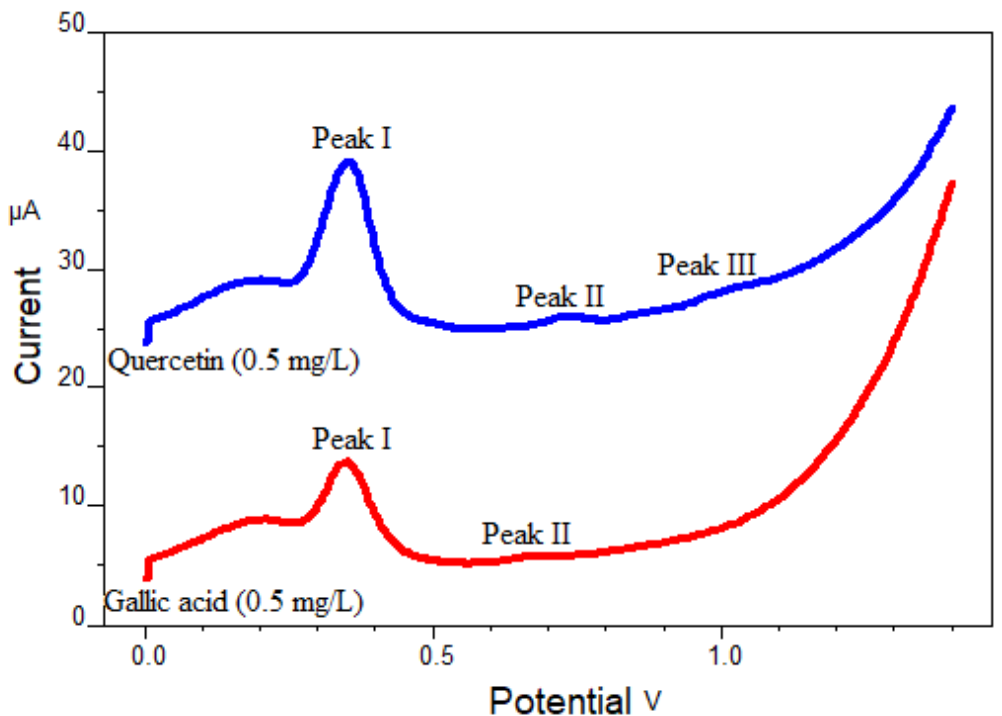

Figure 3. SWS voltammograms for the gallic acid and quercetin $\left(\mathrm{CPE}, \mathrm{pH} 4.0 \mathrm{BR}\right.$ buffer solution, $\mathrm{t}_{\mathrm{b}}=30 \mathrm{~s}, \mathrm{E}_{\mathrm{b}}=0 \mathrm{mV}, \Delta \mathrm{E}=50 \mathrm{mV}, \Delta \mathrm{E}_{\mathrm{b}}=$ $5 \mathrm{mV}$ ve $f=100 \mathrm{~Hz})$

SWS voltammograms of Turkish and Filter coffee samples brewed with different roasted beans under SWSV operating conditions for the standard antioxidant compounds as gallic acid and quercetin were taken on $\mathrm{CPE}$ in $\mathrm{pH}$ 4.0 BR buffer solution (Figure 4). According to the results of the SWSV, it has been found that it contains the most antioxidant capacity (TAC) in Turkish and Filter coffees prepared with low roasted coffee beans (Table 3). For Turkish coffee, the TAC in terms equivalent of gallic acid and quercetin was as $40.143 \pm 1.143$ and $19.580 \pm 0.558$, respectively. These values for filter coffee were found as $92.869 \pm 2.613$ and 45.298 \pm 1.274 . According to the method of roasting, there was a significant decrease in the amount of antioxidants in both coffees prepared with medium and dark coffee beans. In addition, while total antioxidant capacity (TAC) cannot be determined by CV in Turkish coffee prepared with dark roasted coffee beans, TAC analysis was performed in same sample with the SWSV method.
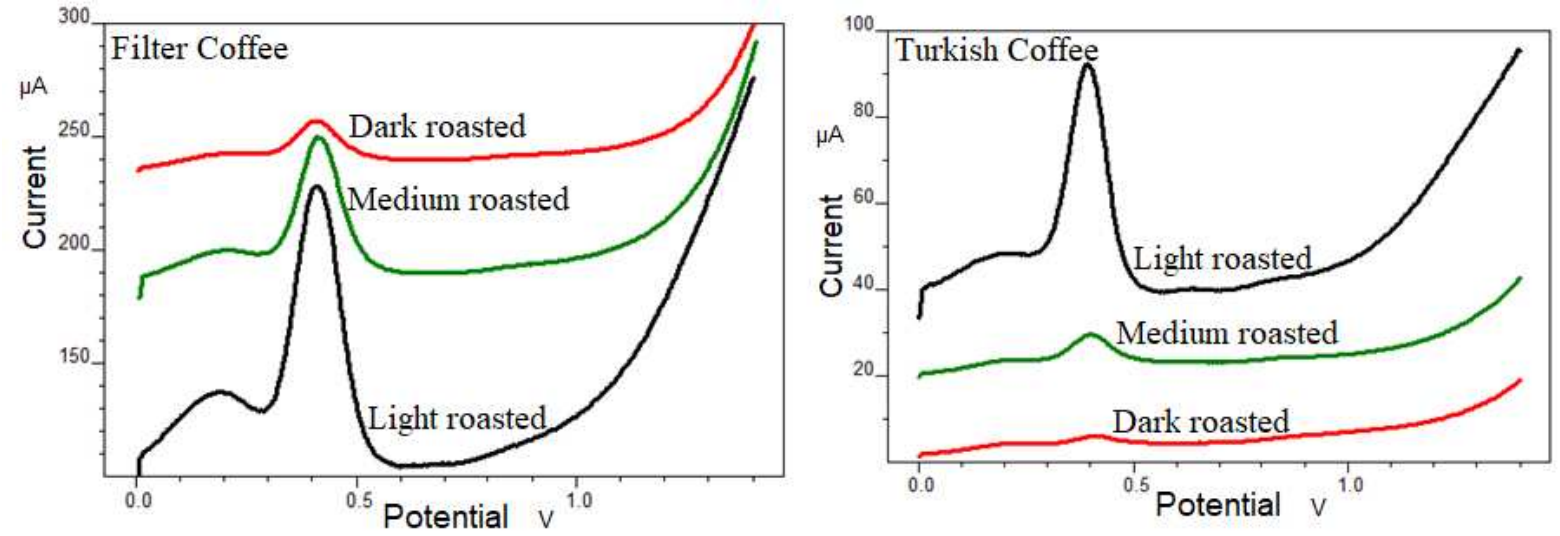

Figure 4. SWS voltammograms for Turkish and Filter Coffee samples prepared with different coffee beans $\left(C P E, t_{b}=30 s, E_{b}=0 m V, \Delta E=\right.$ $50 \mathrm{mV}, \Delta \mathrm{E}_{\mathrm{b}}=5 \mathrm{mV}$ ve $f=100 \mathrm{~Hz}$ ) 


\section{Differential Pulse Stripping Voltammetry}

Differential Pulse Stripping Voltammetry (DPSV) is the most commonly has been used in qualitative and quantitative analysis of many electro-active analytes such as antioxidant, drug, pesticide and heavy metal etc. Due to the fact that it is very sensitive and the waste current (noise) is very low, the DPSV technique makes it possible to analyze even many trace materials at nano-molar level. For these reasons, the DPSV technique has attracted great interest from scientists. It was one of the first preferred techniques among electrochemical analysis methods. Here, optimal experimental conditions of DPSV were initially assigned for the determination of Gallic acid and Quercetin on CPE in $\mathrm{pH} 4.0$ buffer solutions (Table 4).

Table 4. Optimum module parameters of DPSV technique on carbon paste electrode (CPE)

\begin{tabular}{lc}
\hline Parameters & Optimum Values \\
\hline Pulse Amplitude $(\Delta \mathrm{E})$ & $50 \mathrm{mV}$ \\
Pulse period $\left(\mathrm{E}_{\mathrm{t}}\right)$ & $10 \mathrm{~ms}$ \\
Scan rate & $50 \mathrm{mV} / \mathrm{s}$ \\
Step Potential $\left(\Delta \mathrm{E}_{\mathrm{b}}\right)$ & $5 \mathrm{mV}$ \\
Accumulation Potantial $\left(\mathrm{E}_{\mathrm{b}}\right)$ & $0 \mathrm{mV}$ \\
Accumulation Time $\left(\mathrm{t}_{\mathrm{b}}\right)$ & $30 \mathrm{~s}$ \\
Support Electrolyte & $\mathrm{pH} 4.0$ Britton-Robinson buffer \\
\hline
\end{tabular}

DPS voltammograms were collected using CPE in the presence of $5 \mathrm{mg} / \mathrm{L}$ standard quercetin and gallic acid under the optimal experimental conditions of DPSV (Figure 6). While for the gallic acid, two anodic peaks at $320 \mathrm{mV}$ and $665 \mathrm{mV}$ were obtained, quercetin exhibited tree oxidation peaks at $320 \mathrm{mV}, 705 \mathrm{mV}$ and $995 \mathrm{mV}$ on CPE in pH 4.0 Britton-Robinson buffer solutions. However, since the peak currents at $675 \mathrm{mV}$ for gallic acid and $735 \mathrm{mV}$ and $1025 \mathrm{mV}$ for quercetin are very low. So that peak currents for the both agent at $320 \mathrm{mV}$ were used when calculating the total antioxidant capacity (TAC) as equivalent gallic acid and quercetin in coffee samples.

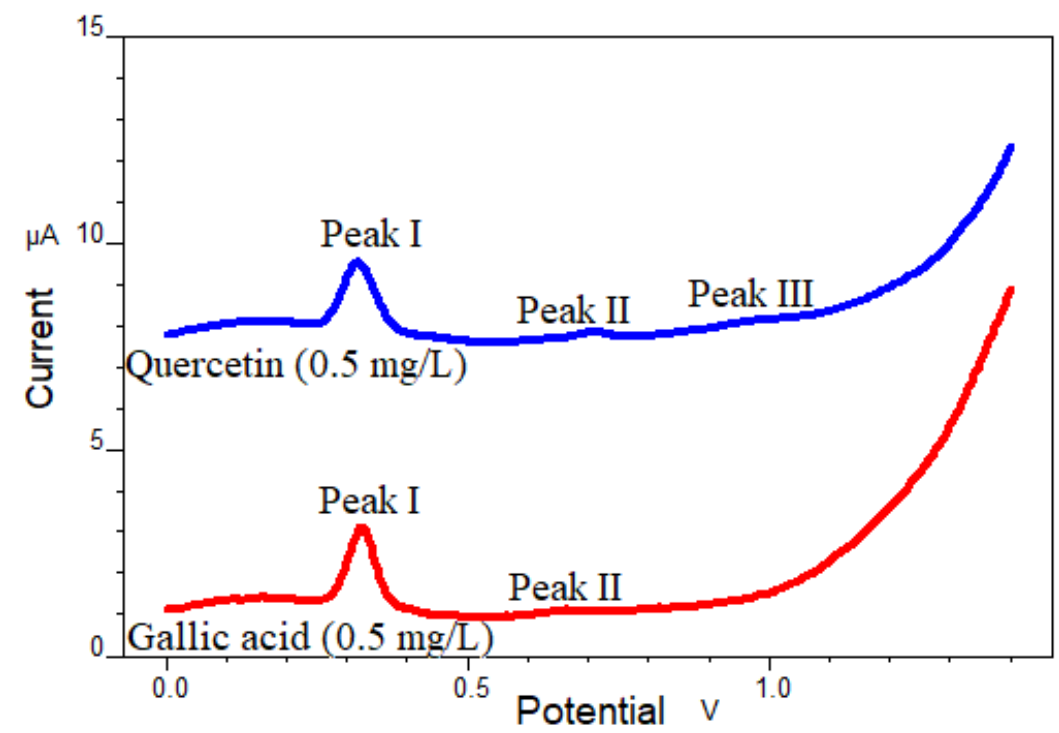

Figure 5. DPS voltammograms for the gallic acid and quercetin $\left(\mathrm{CPE}, \mathrm{pH} 4.0 \mathrm{BR}\right.$ buffer solution, $\mathrm{t}_{\mathrm{b}}=30 \mathrm{~s}, \mathrm{E}_{\mathrm{b}}=0 \mathrm{mV}, \Delta \mathrm{E}=50 \mathrm{mV}, \Delta \mathrm{E}_{\mathrm{b}}=$ $5 \mathrm{mV}$ ve scan rate $=50 \mathrm{mV} / \mathrm{s}, \mathrm{E}_{\mathrm{t}}=10 \mathrm{~ms}$ ) 


\begin{tabular}{|c|c|c|}
\hline & $\begin{array}{l}\text { BŞEÜ Fen Bilimleri Dergisi } \\
7(1), 382-393,2020\end{array}$ & $\begin{array}{r}\text { BSEU Journal of Science } \\
\text { DOI: } 10.35193 / \text { bseufbd.736123 }\end{array}$ \\
\hline U & & $8-7575$ (http://dergipark.gov.tr/bseufbd) \\
\hline
\end{tabular}

DPS voltammograms of Turkish and Filter coffee samples brewed with different roasted beans under operating conditions for the standard antioxidant compounds as gallic acid and quercetin were taken on CPE in pH 4.0 BR buffer solution (Figure 4). According to the results of the DPSV for the coffee sample, it has been found that it contains the most antioxidant capacity (TAC) in Turkish and Filter coffees prepared with low roasted coffee beans (Table 5). For Turkish coffee, the TAC in terms equivalent of gallic acid and quercetin was as $30.711 \pm 0.976$ and $36.634 \pm 1.166$, respectively. These values for filter coffee were found as $58.993 \pm 1.14$ and 70.373 \pm 1.816 . According to the method of roasting, there was a significant decrease in the amount of antioxidants in both coffees prepared with medium and dark coffee beans. In addition, while total antioxidant capacity (TAC) cannot be determined by CV in Turkish coffee prepared with dark roasted coffee beans, TAC analysis was performed in same sample with the DPSV method.

Table 5. Total TAC values as equivalent gallic acid and quercetin by DPSV for Turkish and Filter coffee samples, $\mathrm{n}=3$.

\begin{tabular}{|c|c|c|c|c|}
\hline \multirow{3}{*}{ Coffee Bean } & \multicolumn{2}{|c|}{$\begin{array}{c}\text { Equivalent } \\
\text { Gallic Acid (g/L) }\end{array}$} & \multicolumn{2}{|c|}{$\begin{array}{c}\text { Equivalent } \\
\text { Quercetin (g/L) }\end{array}$} \\
\hline & \multicolumn{2}{|c|}{ Brewing technique } & \multicolumn{2}{|c|}{ Brewing technique } \\
\hline & Turkish coffee & Filter coffee & Turkish coffee & Filter coffee \\
\hline Light roasted & $30.711 \pm 0.976$ & $58.993 \pm 1.14$ & $36.634 \pm 1.166$ & $70.373 \pm 1.816$ \\
\hline Medium roasted & $1.669 \pm 0.064$ & $9.853 \pm 0.234$ & $1.991 \pm 0.076$ & $11.753 \pm 0.280$ \\
\hline Dark roasted & $0.676 \pm 0.018$ & $5.879 \pm 0.099$ & $0.807 \pm 0.021$ & $7.013 \pm 0.118$ \\
\hline
\end{tabular}
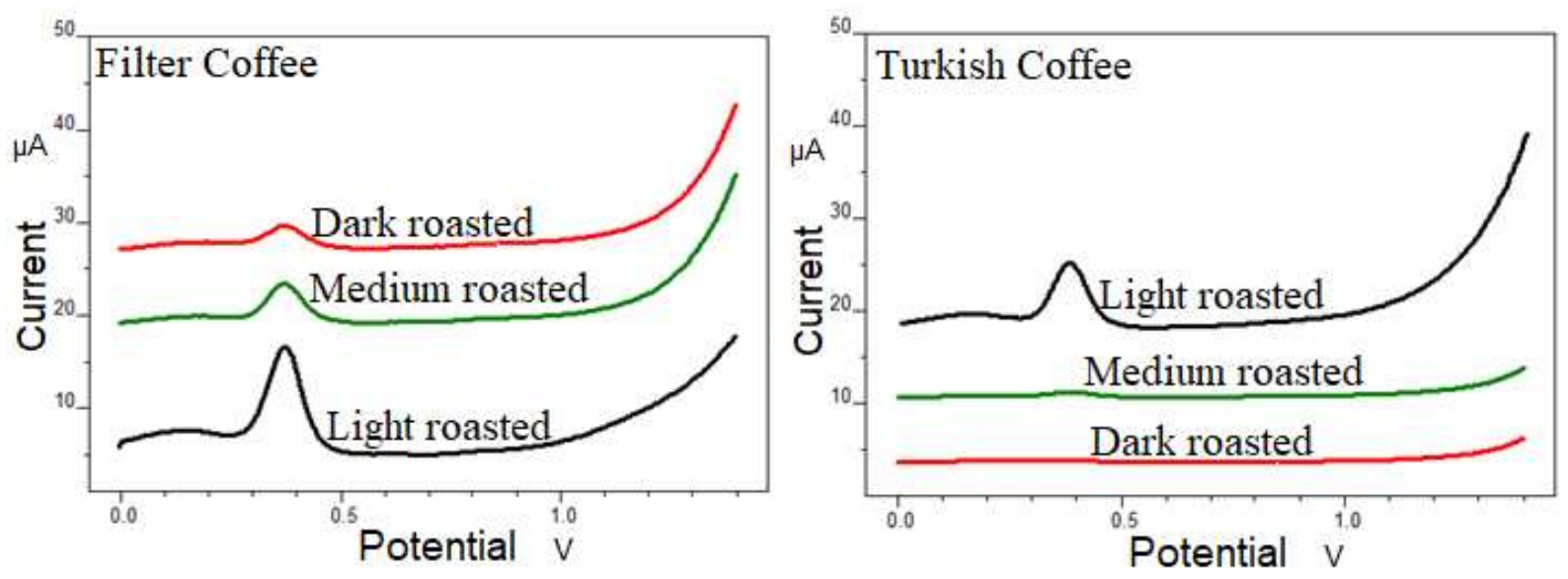

Figure 6. DPS voltammograms for Turkish and Filter Coffee samples prepared with different coffee beans $\left(\mathrm{CPE}, \mathrm{t}_{\mathrm{b}}=30 \mathrm{~s}, \mathrm{E}_{\mathrm{b}}=0 \mathrm{mV}, \Delta \mathrm{E}=\right.$ $50 \mathrm{mV}, \Delta \mathrm{E}_{\mathrm{b}}=5 \mathrm{mV}$ ve scan rate $=50 \mathrm{mV} / \mathrm{s}, \mathrm{E}_{\mathrm{t}}=10 \mathrm{~ms}$ )

\section{CONCLUSIONS}

In the present study, electrochemical applications such as cyclic (CV), square wave stripping (SWSV) and differential pulse striping (DPSV) voltammetric techniques for determination of total antioxidant capacity (TAC) in Turkish and Filter coffee samples were carried using carbon paste electrode (CPE). The operating models of SWSV and DPSV were evaluated for the gallic acid and quercetin as reference antioxidant agents in $\mathrm{pH}$ 4.0 Britton-Robinson buffer solutions. The anodic peak for the both agents at $350 \mathrm{mV}$ was taken a reference point for the analysis of TAC. TAC values were successfully calculated as equivalent gallic acid and quercetin in Turkish and Filter coffee samples prepared with different beans such as light, medium and dark by using all the recommended electrochemical methods (CV, SWSV and DPSV). The maximum antioxidant capacity in coffee samples was found by prepared the light roasted beans for the two coffee types. Consequently, electrochemical 
methods such as CV, SWSV and DPSV can be alternative to evaluate TAC in food samples to conventional analytical methods due to they are fast, reliable, fully validated and without any pretreatment.

\section{ACKNOWLEDGMENT}

This study is performed as a multidisciplinary Master of Science thesis study of Sevinç Yıldırım with the advisor Ilkay Gok and co-advisor Ersin Demir. Also, we would like to thank Kurukahveci Mehmet Efendi Mahdumları Ltd. Şti. for purchasing chemicals and some equipment used during analysis, Arzum Elektrikli Ev Aletleri San. ve Tic. A.Ş. for donation of Turkish coffee machine and Gastro Coffee Roastery Ltd. Şti. for preperation and donation of hand crafted specialty coffee samples and providing espresso coffee machine.

\section{REFERENCES}

[1] Cemal, K., \& Recep P. (2015). Doğal Antioksidanların Sınıflandırılması ve İnsan Sağlığına Etkileri. Turkish Journal of Agriculture - Food Science and Technology, 3(4), 226-234.

[2] Michael, L., Klaudia, J., Patrik, P., Kamil, K., Kamil, M. \& Marian V. (2018). Free Radicals and Antioxidants in Human Disease. Nutritional Antioxidant Therapies: Treatments and Perspectives. Springer,

[3] Helmut, S., Carsten, B. \& Dean P. J. (2017). Oxidative Stress. Annual Review of Biochemistry, 86, 715-748.

[4] Helmut, S. \& Enrique, C. (1985). Oxidative stress: damage to intact cells and organs. Philosophical Transactions of the Royal Society, 311, 617-631.

[5] Enrique, C. \& Kelvin, K. A. D. (2000). Mitochondrial Free Radical Generation, Oxidative Stress, and Aging. Free Radical Biology \& Medicine, 29 (3/4), 222-230.

[6] Hatice, T., İlhami, G., Ercan, Bursal, Ahmet, C. G., Saleh, H. A. \& Ekrem, K. (2017). Antioxidant Activity and Phenolic Compounds of Ginger (Zingiber Officinale Rosc.) Determined by HPLC-MS/MS. Journal of Food Measurement and Characterization, 11, 556-566.

[7] Geir, B. \& Salvatore, C. (2017). Role of Oxidative Stress and Antioxidants in Daily Nutrition and Human Health. Nutrition, 33, 311-321.

[8] Ergul, B. K. (2016). The Importance of Antioxidants Which Play the Role in Cellular Response Against Oxidative/Nitrosative Stress: Current State. Nutrition Journal, 15, 17.

[9] Lien, A. P. H., Hua, H. \& Chuong, P. H. (2008). Free Radicals, Antioxidants in Disease and Health. International Journal of Biomedical Science, 4(2), 89-96.

[10] Emad S. \& Ghada, M. A. (2018). Antioxidants in Foods and Its Applications. IntechOpen, London, United Kingdom.

[11] Lobo, V., Patil, A., Phatak, A. \& Chandra, A. (2010). Free Radicals, Antioxidants and Functional Foods: Impact on Human Health. Pharmacognosy Reviews, 4(8), 118-126.

[12] A. R. Sen \& P.K. Mandal, (2017). Use of Natural Antioxidants in Muscle Foods and their Benefits in Human Health: An Overview. International Journal of Meat Science, 7(1), 1-5.

[13] Drazenka, K. \& Arijana, B. (2014). Antioxidants in Coffee. Processing and Impact on Antioxidants in Beverages, 25-32

[14] Pawel, G., Krzysztof, D., Aleksander, S., Jolanta, T. G., Michal, M. \& Krzysztof, P. (2016). Contribution of phenolic acids isolated from green and roasted boiled-type coffee brews to total coffee antioxidant capacity. European Food Research and Technology, 242, 641-653. 
[15] Daniel, B. R., Antonio, C., Jose, C. C., Amparo, A. T. \& Jolanta, T. G. (2017). Evaluation of the Antioxidant Capacity, Furan Compounds and Cytoprotective/Cytotoxic Effects upon Caco-2 Cells of Commercial Colombian Coffee. Food Chemistry, 219, 364-372.

[16] Birsen, Y., Nilüfer, A. T. \& Saniye, S. (2017). Turkish cultural heritage: a cup of coffee. Journal of Ethnic Foods, 4(4), 213-220.

[17] Solange, I. M., Ercilia, M. S. M., Silvia, M. \& Jose, A. T. (2011). Production, Composition, and Application of Coffee and Its Industrial Residues. Food and Bioprocess Technology, (4), Article number: 661.

[18] Jane, V. H. \& Balz, F. (2006). Coffee and Health: A Review of Recent Human Research. Critical Reviews in Food Science and Nutrition, 46, 101-123.

[19] Adriana F. (2018). Nutritional and health effects of coffee. Burleigh Dodds Science Publishing, Cambridge, UK.

[20] Prasun, B., Amit, K. G. \& Chandrasekhar, G. (2012). Recent Developments on Polyphenol-Protein Interactions: Effects on Tea And Coffee Taste, Antioxidant Properties and The Digestive System. Food \& Function, 6(3), 592-605.

[21] Alessia, P., Antonio, Z., Roberto, L., Giancarlo, M. \& Rita, P. (2013). Recovery of Natural Antioxidants from Spent Coffee Grounds. Journal of Agricultural and Food Chemistry, 61(17), 4162-4168.

[22] Tena, N., Drazenka, K., Ana, B. C., Dunja, H. \& Maja, B. (2012). Bioactive Composition and Antioxidant Potential of Different Commonly Consumed Coffee Brews Affected by Their Preparation Technique and Milk Addition. Food Chemistry, 134(4), 1870-1877.

[23] Telma, A. F. C., Marcela, P. M., Thaise, P. M., Daniela, M. O., Marcelo, M. R., Cibelem, I. B., Carmen, G.C. V., Bruno, M. M., Daniela, T., Vera, L. T., Luiz, A. M. C., \& Elizabeth, A. F. S. T. (2012). Medium Light and Medium Roast Paper-Filtered Coffee Increased Antioxidant Capacity in Healthy Volunteers: Results of a Randomized Trial. Plant Foods for Human Nutrition, 67, 277-282.

[24] Tolgahan, K. \& Vural, G. (2016). Effect of Roasting and Brewing On The Antioxidant Capacity of Espresso Brews Determined by the QUENCHER Procedure. Food Research International, 89(2), 976-981.

[25] Irda, F. \& Annisa, K. R. (2016). Antioxidant Activities of Arabica Green Coffee From Three Regions Using ABTS And DPPH Assays. Asian Journal of Pharmaceutical and Clinical Research, 9(2), 189-193.

[26] Magdalena, J.S., Aleksandra, S., Krystyna, P. \& Maria, P. D. P. (2016). Chlorogenic Acids, Caffeine Content and Antioxidant Properties of Green Coffee Extracts: Influence of Green Coffee Bean Preparation. European Food Research and Technology, 242, 1403-1409.

[27] Vignoli, J. A., Bassoli, D. G. \& Benassi, M. T. (2011). Antioxidant Activity, Polyphenols, Caffeine and Melanoidins in Soluble Coffee: The Influence of Processing Conditions and Raw Material. Food Chemistry, 124, 863-868.

[28] Luis, M. M., Marcela, A. S., Salette, R., Jose, L. F. C. L. \& Antonio, O. S. S. R. (2006). Automatic Method for the Determination of Folin-Ciocalteu Reducing Capacity in Food Products. Journal of Agricultural and Food Chemistry, 54(15), 5241-5246.

[29] Ersin D. (2019). A Simple and Sensitive Square Wave Stripping Pathway for the Analysis of Desmedipham

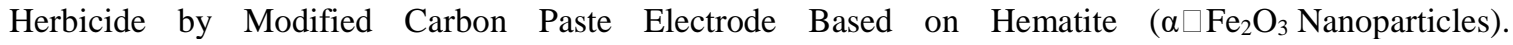
Electroanalysis, 31(8), 1545-1553.

[30] Yongnian, N., Ping, Q. \& Serge, K. (2005) Simultaneous Voltammetric Determination of Four Carbamate Pesticides with the Use of Chemometrics. Analytica Chimica Acta, 537(1-2), 321-330. 
[31] Burcu, D. T., Sibel, A. O. \& Bengi U. (2010). The Analytical Applications of Square Wave Voltammetry on Pharmaceutical Analysis. The Open Chemical and Biomedical Methods Journal, 3, 56-73.

[32] Ersin, D., Ahmet, S., Franck, M. T. K., Erhan, D. \& Hassan, Y. A. E. (2020). Electrochemical Evaluation of the Total Antioxidant Capacity of Yam Food Samples on a Polyglycine-Glassy Carbon Modified Electrode. Current Analytical Chemistry, 16(2), 176-183.

[33] Ersin, D (2019). Sensitive and Selective Pathway of Total Antioxidant Capacity in Commercially Lemon, Watermelon and Mango-pineapple Cold Teas by Square Wave Adsorptive Stripping Voltammetry. Gazi University Journal of Science, 32(4), 1123 - 1136.

[34] Ahmet, S., Tamara, B., Erhan, D. \& Mahmut, D. (2019). Direct and Fast Electrochemical Determination of Catechin in Tea Extracts using SWCNT $\square$ Subphthalocyanine Hybrid Material. Electroanalysis, 31(9), $1697-1707$.

[35] Ahmet, S., Alirez, K., Erhan, D. \& Esmail, D. (2020). Ultrasensitive Detection of Rutin Antioxidant Through a Magnetic Micro-Mesoporous Graphitized Carbon Wrapped Co Nanoarchitecture. Sensors and Actuators B: Chemical, 312, 127939.

[36] Ahmet, S., Baybars, K., Erhan, D., Tamara, B. \& Mahmut, D. (2018). 3D SWCNTs-Coumarin Hybrid Material for Ultra-Sensitive Determination of Quercetin Antioxidant Capacity. Sensors and Actuators B: Chemical, 267, 165-173. 